\title{
JOSEPH MECKE: AN APPRECIATION
}

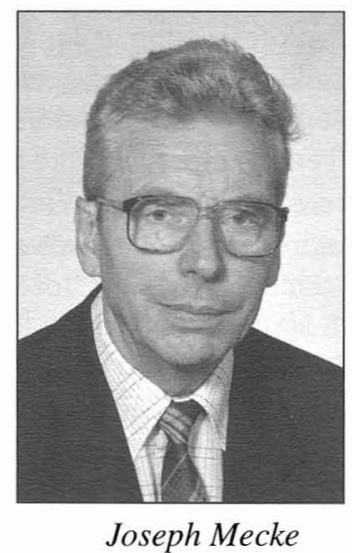

Joseph Mecke, Professor of Mathematics at the Friedrich Schiller University, Jena, celebrates his 65th birthday on 18 February 2003. To commemorate this happy occasion, the signatories invited some colleagues, friends and former students to honour Joseph as a mathematician, teacher and research worker by submitting research articles to this issue of Advances in Applied Probability. We trust that the following papers will pay homage to the influence he has exerted in point process theory and stochastic geometry during his distinguished career.

Joseph was born in the German village of Niederorschel on 18 February 1938; he has two sisters. His birthplace lies in the Eichsfeld, a Roman Catholic region in the otherwise protestant Thuringia. During the years of the atheistic communist regime in East Germany, he always retained a deep sense of his ties to his religion. His first years of elementary school fell in Nazi times; even as a boy he disliked militarism and nationalism arising from whatever source. Later he attended secondary school in Worbis, one of the towns of the Eichsfeld. Here he found an appreciative teacher who encouraged his striking mathematical talent.

From 1956 to 1961 he studied mathematics at the University of Jena; he also attended lectures on physics. Joseph finished his studies with a paper on number theory, on cubic number fields, for which he received an award of the Faculty of Natural Sciences.

Joseph began his academic career as an assistant at the Department of Mathematics in Jena. Under the guidance of Professors Johannes Kerstan and Klaus Matthes (at the time the leading East German mathematicians in the field of probability), he worked in the field of point processes and random measures. In 1964 he was awarded his doctorate for a thesis on point processes.

As was usual for promising young scientists at that time in East Germany, he spent time in the Soviet Union: for the academic year 1964/65 he visited Boris V. Gnedenko at Lomonosov University in Moscow.

Based on the first series of his now classical papers on point processes, random measures and Palm distributions, in 1969 he earned the second German doctor degree, the Habilitation. He then achieved the position of Dozent, a level comparable to that of a lecturer or an assistant professor. In 1971, together with four other mathematicians (including Kerstan and Matthes), he was awarded the Nationalpreis der DDR, the highest decoration for scientists in East Germany. 
This high honour was possible even for such a notorious non-party member such as Joseph, but nevertheless he was not permitted to attend the international point process conference held in New York in that same year. Moreover, two years later, Joseph (then aged 35) was compelled to serve six months in the East German army.

Supported by Kerstan, who was a committed member of the DDR Communist Party, in 1977 Joseph was appointed to a full professorship at Jena. Since 1978 he has been the head of a research team working in the field of stochastic geometry. He was an early pioneer in developing the value of marked point processes and random measures for stochastic geometry, and created the fundamentals of the general theory of fibre processes and random tessellations. Among his most prominent pupils were Werner Nagel, Viola Weiß and C. Thomas; in addition, Dietrich Stoyan has enjoyed many years of close research cooperation with Joseph.

After 1978, some limited opportunities arose for Joseph to travel to western countries. For example, in 1985 he was a much appreciated visiting lecturer at Strathclyde University in Glasgow, where he cooperated with Brian Ripley and Wilfrid S. Kendall. After the re-unification of Germany, Joseph became deputy to the dean of his faculty, and since 1996 he has been the head of the Institute of Stochastics.

Joseph is a well-loved academic teacher. His lectures are particularly clear and well organised. He considers it a very important duty to nurture and to motivate his students, and the care which he takes over the content of his lecture courses is strongly informed by his concern for his students' needs in their subsequent professional lives. It is particularly notable how many of his most successful research students are women.

Joseph has published more than 50 papers, mainly on point processes, random measures and stochastic geometry. His papers are the result of an intensive search for the simplest and clearest concepts and the most elegant proofs. At least two fundamental theorems of point process theory bear or should bear Joseph's name: the Campbell-Mecke theorem and the Slivnyak-Mecke theorem. The paper of Cowan et al. in this issue gives good arguments for naming the Slivnyak theorem about the form of the Palm distribution of the Poisson process after Slivnyak and Mecke. Below, we present Mecke's own selection from his published papers.

In recent years, Joseph has focused on the study of random tessellations and their optimality properties. We look forward to the continuation of Joseph's successful research work after 2003 !

No account of Joseph Mecke's activities is complete without reference to his basic kindness, his reliability as a scientific colleague, and his habit of thoroughness and clarity of thought. $\mathrm{He}$ is a deeply lovable person, modest, careful and reserved; a very good and patient partner in mathematical and other discussions. His main non-mathematical interest lies in problems of natural science, particularly botany; it is a happy fact that Jena is a German Eldorado for orchids! As a student, he liked to study mathematical papers outdoors, so enjoying both mathematics and nature.

It is a privilege to have gathered together the articles in this issue of Advances in Applied Probability, and to have the opportunity to write Happy Birthday, Joseph, and many more happy years indeed.

University of Aarhus

Eva B. Vedel Jensen

Bergakademie Freiberg

Dietrich Stoyan

February 2003 


\section{Selected publications of Joseph Mecke}

Mecke, J. (1967). Stationäre zufällige Maße auf lokalkompakten Abelschen Gruppen. Z. Wahrscheinlichkeitsth. 9, 36-58.

MECKE, J. (1968). Eine charakteristische Eigenschaft der doppelt stochastischen Poissonschen Prozesse. Z. Wahrscheinlichkeitsth. 11, 74-81.

MecKe, J. (1968). Invarianzeigenschaften allgemeiner Palmscher Maße. Math. Nachr. 65, 335-344.

Matthes, K., Kerstan, J. And Mecke, J. (1978). Infinitely Divisible Point Processes. John Wiley, New York.

Mecke, J. (1980). Palm methods for stationary random mosaics. In Combinatorial Principles in Stochastic Geometry (in Russian), ed. R. V. Ambartzumian, Armenian Academy of Science, Erevan, pp. 124-132.

Stoyan, D. And Mecke, J. (1983). Stochastische Geometrie. Eine Einführung. Akademie, Berlin.

Mecke, J. (1984). Parametric representation of mean values for stationary random mosaics. Math. Operationsforsch. Statist. Ser. Statist. 15, 437-442.

Mecke, J. (1984). Random tessellations generated by hyperplanes. In Stochastic Geometry, Geometric Statistics, Stereology, eds R. V. Ambartzumian and W. Weil, Teubner, Leipzig, pp. 104-109.

Mecke, J. And Thomas, C. (1986). On an extreme value problem for flat processes. Commun. Statist. Stoch. Models 2, 273-280.

MeCKe, J. (1988). Random $r$-flats meeting a ball. Arch. Math. 51, 378-384.

Mecke, J. (1988). An extremal property of random flats. J. Microscopy 151, 205-209.

Mecke, J., Schneider, R., Stoyan, D. And WeIl, W. (1990). Stochastische Geometrie. Birkhäuser, Basel.

Ambartzumjan, R. V., Mecke, J. and Stoyan, D. (1993). Geometrische Wahrscheinlichkeiten und Stochastische Geometrie. Akademie, Berlin.

Stoyan, D., Kendall, W. S. And Mecke, J. (1995). Stochastic Geometry and Its Applications, 2nd edn. John Wiley, New York.

Mecke, J. (1995). Inequalities for the anisotropic Poisson polytype. Adv. Appl. Prob. 27, 56-62.

Mecke, J. (1999). On the relationship between the 0 -cell and the typical cell of a stationary random tessellation. Pattern Recognition 32, 1645-1648. 